\title{
THREAT OF CHEMICAL TERRORISM IN THE UNDERGROUND
}

\author{
Barbora SCHÜLLEROVÁ ${ }^{1}$, Otakar J. MIKA², Vladimír ADAMEC ${ }^{3}$
}

\section{Review article}

Abstract:
The paper provides a brief description of the Prague Metro focusing on the potential
chemical threats by chemical warfare agents. Detailed evaluation of the possibility of
abuse of chemical warfare nerve agents is presented in different conditions in the Prague
Metro system as simulated by a TEREX computer program. In conclusion, the results are
evaluated by a SWOT analysis referring to many domestic scientific works dedicated to
the protection of population against the effects of chemical terrorism.
Chemical terrorism, chemical warfare agents, terrorist attacks, Prague Metro, Integrated
Emergency System.

\section{Introduction}

Sustainable development is hardly possible without both internal and external sustainable safety, which is interrelated with other segments of society development. At present, organized crime, with terrorism being its major force, is among the current threats against society. Particularly group terrorism is a serious threat taking on international and global character.

In terms of the terrorists' targets, attacks of all the usual and progressive forms of terrorism may be expected using the chemical, biological, radiological, and nuclear substances (CBRN) against population as well as against all kinds of traffic infrastructure. Underground traffic systems are characterised by closed or semi-closed areas allowing rather limited movement especially if the numbers of passengers increase such as during rush hours. In these periods, such spaces become ideal for terrorist attacks, particularly chemical ones. It is then little surprising that the first large chemical terrorist attack was carried out in the Tokyo subway, which transports about million people commuting daily from the city suburbs (Okumura et al., 1996; Matoušek et al., 2008). It was this attack that became an initial impulse towards increasing population safety and protection. This gave importance to studies on personal protection equipment, resistance of subways to attacks, etc. (Koenig et al., 2007; Angeloudis et al., 2006). Thus, it is possible to find inspiration for protective and preventive measures in countries with extensive underground traffic systems such as in China or Japan which, due to their previous experience and the large numbers of people transported, require high security.

Regardless of how realistic or probable it is in our conditions to expect terrorist attacks, it must be assumed that the Prague underground traffic system called Metro might be among the places potentially threatened by chemical terrorist attacks (Mika, 2013). For this reason, it is necessary to study the possibilities and circumstances of such attacks to be able to counter by preventive, repressive, protective, rescue, liquidation, and corrective measures. As in other countries with underground traffic, in the Czech Republic, too, terrorist attacks are no doubt most likely to be carried out during the morning or afternoon rush hours when the crowd concentration reaches its peak, particularly at junctions and interchange stations.

In providing population with protection against total danger of chemical terrorism, it is important to mention the current international and national legislation. This includes the Chemical Weapons Convention of 1993, Act no. 19/1997 Coll., and Regulation no. 208/2008 Coll., to this Act, which specifies in detail dangerous chemical substances listing the basic conditions of handling highly hazardous substances, defining the amounts of dangerous substances that must be reported and listing the requirements of the structuring of the registration of named substances. It divides the

\footnotetext{
Brno University of Technology, Institute of Forensic Engineering, Brno, Czech Republic, barbora.schullerova@usi.vutbr.cz Tomas Bata University in Zlín, Faculty of Logistics and Crisis Management, Zlín, Czech Republic, otakar_mika@email.cz Brno University of Technology, Institute of Forensic Engineering, Brno, Czech Republic,vladimir.adamec@usi.vutbr.cz
} 
substances into several lists according to the danger they pose (Regulation, 2008).

A new type activity was issued in 2013, (STČ-13/IZS „Response to a Chemical Attack in the Metro") focusing on chemical terrorism in the condition of the Prague Metro (STČ, 2013). This is a non-public material created as a result of long tests and experiments, which also makes use of the pivot operation of a simulation of contaminants spreading in the Prague Metro where strong airflows exist with special effects such as air piston effect with the air being pushed out of a tunnel by the train. The document sets a number of tasks and measures to be carried out by the basic and other parts of the Integrated Emergency System (IES) while describing the procedures to be carried out by rescue teams, cooperation between the parts and listing other details of a successful intervention after chemical attack. It is no doubt a unique planning material that may save tens or even hundreds of human lives or substantially protect the health of the attacked and affected people if carried out completely (Konečný, 2013). In October 2014, a large-scale „Metro 2014““ drill was carried out focused on a terrorist attack using chemical warfare agents. The mock-object discovered was a broken bottle with fluid of unknown origin leaking out producing fumes having adverse effects on the health of the passengers in the Metro. The drill was attended by IES units, the Prague Public Transport Company, and other units involved to test their ability to carry out the procedures required by the above-mentioned STČ document.

By its conception and, especially, by its content and scope of the treatment of an emergency, this is a rather special approach to a methodological material for the activity of the Integrated Emergency System parts. It is expected that a potential underground chemical attack will, in addition to the Metro, affect the life of the whole capital (Klouda, 2008). A traffic breakdown in the entire city may be expected because the Prague Metro with its three traffic lines forms the basic and main backbone of the city transport.

Clearly, in our conditions, the inestimable impacts of strikes carried out by suicide terrorists ready to sacrifice their lives because of extreme religion, ethnic, or political fanaticism can be excluded (Mika, 2013). However, this situation may be subject to a dramatic change due to the increasing tourism but also because of the large population migration. It is well known that, at present, certain Muslim communities are coming into existence also in the Czech Republic (Pokorný, 2014) including the building of the basic religious symbols such as Mosques, prayer rooms, and other buildings.

\section{Materials and methods}

At the first stage of a study of chemical terrorism in the conditions of the Prague Metro, a thorough analysis was made of the current conditions of the underground traffic system as mentioned in the introduction. Materials and data on the Prague Metro were found in statistical yearbooks, information bulletins of the Prague Public Transport Company, and in technical literature (Statistical Report, 2013; DPP, 2013a; DPP, 2013b; Konečný, 2013).

A SWOT (Strengths, Weaknesses, Opportunities, Threats) analysis was made to analyze the results obtained to evaluate both the external and internal factors affecting the given problem or subject (Management Mania, 2013). The results were shown in a SWOT analysis table (Tab. 5). Also, an analysis was made of the possibilities of misuse and effects of the nerve-paralyzing chemical warfare agents in the conditions of the Prague Metro using a TEREX computer programme described below.

\section{The Prague Metro - present state}

At present, the Prague Metro has 57 stations and $57 \mathrm{~km}$ of tunnels. The distance between two stations is about 1,000 to 1,200 metres. Every year, it transports about 583,876 passengers, which is $45.02 \%$ of the persons transported by the Prague Integrated Transport System, with 1.6 million passengers transported per day on average (Statistical Report, 2013).

As the city develops, so does the Prague Metro where at present construction work is done to extend the A line. There will be four stations on this line one of them being the Motol station in the vicinity of one of the Czech Republic's largest hospitals. Thus, it may be expected that this part of the extended line, too, will be much frequented with a very high number of passengers. The line should be finished and put into operation in late 2014 to early 2015 (DPP, 2013a).

Another approved Prague Metro development plan is a project to build a $\mathrm{D}$ line with the construction to be launched in 2016. As on the A line, this line, too, will have a major station in the vicinity of the Krč Hospital where a high passenger concentration can be expected. After the construction of the lines planned is finished, the number of passengers will be increased, which will bring about a higher potential threat that must be taken into account when planning for security measures in proportion to the development of the Metro (DPP, 2013b). Specific technical parameters of the Prague Metro are available at the Prague Public Transport Company, the Metro 
operator, at the building companies participating in the development, supplying the ventilating systems, and in research papers (Neplechová and Klouda, 2008; Klouda, 2008; DPP, 2015).

According to experts' opinions, as a transport system, the underground is considerably vulnerable (Konečný, 2013). This is mostly because of the great concentration of persons (passengers) both in the aboveground and belowground stations. The access routes such as underpasses and escalators between the aboveground and belowground stations are also crowded. Planting a timed explosive charge with dangerous chemical substance is relatively easy. This facilitates a terrorist attack in a chosen place at a chosen time. It is easy for the terrorists (attackers) to pick a suitable place and time of the attack by inconspicuously and closely observing for several days the pre-selected exposed places crowded with passengers. One of the numerous security measures implemented in the Prague Metro is PROVAS, an anti-chemical early-warning system that can detect chemical substances including chemical warfare agents and send warnings to the relevant IES units. The large complex system of underground structures including critical infrastructures necessitates the knowledge of the vulnerability (ventilating systems, air flowing, etc.) or, on the contrary, of the security of the system, which is dealt with in detail, for example, in papers by Klouda, 2008; Neplechová and Klouda, 2008; Kozubková et al., 2008.

\section{Nerve- paralyzing warfare chemical agents}

Following an analysis of the present state of the Prague Metro, it was also important that the study should estimate the potential misuse of the nerve-paralyzing warfare chemical agents with the most serious adverse impact. The most dangerous type of chemical terrorism (chemical attack) that involves mass attack on people leading to a high degree of health and irrecoverable losses, that is, to a large number of symptoms of higher acute intoxication forms, requires high toxicity, particularly acute inhalation toxicity inhalation, that corresponds to the way and forms of its potential use. When judging agents most likely to be chosen by chemical terrorists, we have to take into account both the threats posed by the agent and the ease with such an agent can be dispersed, which is mostly by free evaporation in a transport infrastructure space, which is not necessarily identical with judging the dangerousness of warfare agents because, in a battlefield, these can be dispersed simply by explosion, which, basically, must be seen as considerably less suitable in the Metro (Mika, 2013).
In the paper, the study was only concerned with ways of misuse of nerve-paralysing warfare chemical agents in the conditions of the Prague Metro. To a considerable extent, however, the conclusions can also be applied to underground traffic systems in other large world capitals. As only code names of the warfare chemical agents are used in the sequel, these highly dangerous highly and extremely toxic chemical compounds are listed in the below table. The data in Tab. 1 are taken from Matoušek et al. 2005; Mika, 2013; Marrs et al., 2007; Engman and Cassel, 2002; Mika, 2011a.

Tab. 1 Code and chemical names of nerve-paralyzing chemical warfare agents (CWA) (Source: the author)

\begin{tabular}{|l|c|l|}
\hline $\begin{array}{c}\text { Trivial } \\
\text { CWA name }\end{array}$ & $\begin{array}{c}\text { CWA code } \\
\text { name }\end{array}$ & \multicolumn{1}{|c|}{ CWA chemical name } \\
\hline Sarin & GB & $\begin{array}{l}\text { O-isopropyl } \\
\text { methylphosphonofluoridate }\end{array}$ \\
\hline Cyclosarin & GF & $\begin{array}{l}\text { O-cyklohexyl } \\
\text { methylphosphonofluoridate }\end{array}$ \\
\hline Soman & GD & $\begin{array}{l}\text { O-pinakolyl } \\
\text { methylphosphonofluoridate }\end{array}$ \\
\hline VX agent & VX & $\begin{array}{l}\text { O-ethyl S-[2-(diisopropylamino) } \\
\text { ethyl] methylphosphonothiolate }\end{array}$ \\
\hline $\begin{array}{l}\text { VX-R agent } \\
\text { (R-33) }\end{array}$ & R-33 & $\begin{array}{l}\text { O-isobutyl S-[2-(diethylamino) } \\
\text { ethyl] methylphosphonothiolate }\end{array}$ \\
\hline Tabun & GA & $\begin{array}{l}\text { O-ethyl N,N-dimethyl } \\
\text { phosphoramidocyanidate }\end{array}$ \\
\hline
\end{tabular}

\section{Calculation methods and SWOT analysis}

Modelling of warfare chemical agent spreading depends on numerous factors such as air flowing in the underground space. At present, the authors have access to a TEREX (Terrorist Expert) computer program and have used it to make a rough estimate of the spreading of warfare chemical agents in the conditions of the Prague Metro (T-SOFT, 2012). Although the authors know about the existence of other better suited software tools such as Fluent, which can model flowing in underground spaces (Kozubková, 2008), TEREX is primarily designed to quickly and reliably model contingencies to quickly and correctly design various protective, rescue, liquidation, and other measures (Mika and Patočka, 2007; T-SOFT, 2012). Unlike the free ALOHA (CAMEO, 2013) program, it helps model even nerve-paralyzing warfare chemical agents such as the below listed sarin, soman, and tabun. The choice of these agents was the result of an analysis of their effects in the condition of the Metro (see the results). 
For the calculations, the standard conservative conditions were assumed (the most pessimistic conditions), which means that the worst conditions were assumed for the dispersion of the dangerous chemical substance in the air. A temperature of $20^{\circ} \mathrm{C}$, wind speed of $1 \mathrm{~m} / \mathrm{s}$, vertical constancy of the inversion atmosphere. Plane as the surface type in the direction of the dangerous chemical substance spreading. Other conditions can be found directly at each toxic chemical substance. A POISON emergency model (TEREX, 2012) was chosen in the TEREX program designed for modelling poisonous substances, that is, nerve-paralyzing warfare chemical agents in this case. Dispersion of the substance through explosion, spraying, etc. was chosen as the way of substance release.

An important result of the evaluation for warfare chemical agents is the degree of threat to persons by these substances (TEREX output). Another important evaluation result is the recommended measurement of the toxic concentration up to a certain distance from the place of attack. As an input value, TEREX uses the area in hectares (ha) of the contaminated region to evaluate warfare chemical agents.

The modelling was carried out only for the selected nerve-paralyzing warfare chemical agents sarin, soman, and tabun, which is due to the limitations of the TEREX program. Thus, the results obtained can only be regarded as rough because the program does not take into account the specific features of an underground transportation system in terms of the flowing of the contaminate air. The Prague Metro as well as other underground systems such as in Europe is characterized by a high speed of air flowing through the tunnels with the flowing becoming even turbulent in places etc. The modelling of the maximum range of the selected agents is described in the Results chapter (Tab. 2, 3, and 4).

\section{Results}

\section{Analysis of the potential misuse of warfare chemical agents in the condition of the Prague Metro}

Arranging the warfare nerve-paralyzing poisons spread by explosion as is usual in warfare by their dangerousness, which is given by a simultaneous combination of inhalation and percutaneous intoxication, we get an unequivocal result:

- for colder zones, this is the warfare chemical agent sequence: VX - R33 - GD - GB - GA - GF,
- for very warm climatic zone, the order is changed: VX - R33 - GF - GD - GA - GB.

The Prague Metro space may be regarded as a colder (temperate) climatic zone. Dispersion by explosion, however, does not seem to be applicable here, certainly not inside a car and probably in a station either. It may be assumed that the most suitable method of dispersion is free or aided evaporation bringing about dominant inhalation intoxication. In such a case, volatility in addition to toxicity must be taken to consideration as a very significant physical and chemical property of a chemical substance. Under the above circumstances, in terms of danger, the order of the sequence (from the most appropriate to the most inappropriate agent) is substantially different:

- GB - GF - GD - GA - R33 - VX.

Given the above criteria, the strongly toxic while the most volatile sarin (GB) seems to be the most dangerous substance, which is the reason why it will be exclusively considered in the sequel. It is in this way that sarin was probably chosen as the most suitable agent for terrorist attacks by Aum Shinrikyo, the Japanese doomsday cult (Okumura et al., 1996; Mika et al., 2007; Mika et al. 2011b). Modelling the leaking of sarin in the real conditions of the Prague Metro had already been done, for example, for transfer stations focusing on issues related to the outlets of ventilation shafts, which may have a major role in spreading a warfare chemical substance (Klouda et al., 2007; Kozubková et al. 2008; Večerková and Klouda, 2009; Klouda et al., 2011).

It is clear that, given the real potential of spreading techniques, but mainly, given the set of the toxic, physical, and chemical properties, the most likely way of intoxication is acute inhalation poisoning. Nerve-paralyzing substances (sarin above all) are used to disable living creatures. Their effects are manifested symptoms of acute inhalation poisoning (miosis, breathing difficulties) or cause death. Even if sarin's effects are very serious, it only ranks third among nerve-paralyzing poisons (killing $\mathrm{LCt}_{50} 100 \mathrm{mg} \cdot \mathrm{min} / \mathrm{m}^{3}$, disabling Ect 50 $75 \mathrm{mg} \cdot \mathrm{min} / \mathrm{m}^{3}$ ) behind the about three times more toxic soman and the three-to-ten times more toxic VX. However, considering the spreading potential, particularly free evaporation under the given circumstances, then, comparing the volatilities, sarin poses by far the most total danger. The reason is that the maximum concentration (volatility) $\mathrm{C}^{20}{ }_{\text {max }}$ is $11500 \mathrm{mg} / \mathrm{m}^{3}$. This is about five times greater than in soman and thousand times greater than in VX. The high volatility of VX was only investigated 
using the spreading technique in the form of aerosol to simultaneously take advantage of its immense toxicity for unprotected skin if possible through an explosion, which can hardly be expected in a terrorist attack in interior spaces. Such a use is only typical for chemical weapon warfare.

From the above, it follows that to reach the dangerous effect of inhalation intoxication by sarin, that is, 50\% disabling to killing, the dosage used must be between 50 and $100 \mathrm{mg} \cdot \mathrm{min} / \mathrm{m}^{3}$.

For further calculation, another input parameter must be estimated, which is the actual exposure to the sarin fumes, given by the expected time of stay of the persons in the (contaminated) Metro spaces. Considering the sizes of stations and the frequency of trains varying with lines and time of the day, it can be estimated, that the stay of a passenger or group of passengers is not likely to exceed 5 minutes on average from entering the escalator tunnel to waiting for the train to getting on the car or moving in reverse order. This implies that, given the above values, for an exposure of 5 minutes in the interior of the Metro, the necessary target sarin concentration in vapours will be 10 to $50 \mathrm{mg} / \mathrm{m}^{3}$. The situation will be somewhat different inside the cars (Klouda et al., 2011). As the size of the Prague Metro is smaller compared to Paris, London, New York, and other megalopolises where the travelling time from one end of a line to the other may exceed one hour, here the travelling times are much shorter. With the tree lines and the central triangle and given the big frequency of passenger changing lines in the central zones, the average time of staying on a car for passengers travelling between the Prague long-distance bus and railway stations, to the Prague airport, and other passengers may be expected to be about 8 to 12 minutes (also from the authors' own experience). If, for simplicity, we choose an exposure time for a Metro car to be 10 minutes, then the target sarin concentration needed for the car interior will be 5 to $25 \mathrm{mg} / \mathrm{m}^{3}$.

In both the above cases, the target concentrations of warfare chemical agents are only average ones. It is clear that, depending on the method of dispersion, these concentrations will increase step by step and, especially in the case of free evaporation, starting from the zero level. A degree of threat to passengers in the Metro, depending on the way of dispersion, will involve an integral value given by the dynamics of the gradual building of effective concentrations, which must be taken into account when further investigating the ways of chemical attacks. This particularly implies that the initial amounts needed for a given space volume will probably have to be substantially (that is, several times) higher or methods of simple ways of accelerated evaporation will have to be taken into account (Mika, 2013).

Such methods can use the dispersion techniques adequate to the use by terrorists in a confined space, which, however, must not put in danger the chemical terrorists themselves.

\section{Sarin}

The below Tab. 2 shows the results of the modelling by TEREX - POISON model (TEREX, 2012) for sarin, calculating the danger to people through this substance and the recommended investigation of the toxic concentration. In the case of sarin, a different way of substance spreading was chosen: evaporation from a puddle (people are threatened by the chemical substance at a substantially shorter range). Such a way of evaluation was no longer used for other warfare chemical agents.

Tab. 2 Potential misuse of sarin for chemical terrorism (Source: the author, T-SOFT)

\begin{tabular}{|c|c|c|c|c|c|}
\hline $\begin{array}{c}\text { Scenario } \\
\text { code }\end{array}$ & $\begin{array}{c}\text { Contaminated } \\
\text { area [ha] }\end{array}$ & $\begin{array}{c}\text { Dispersion: } \\
\text { persons } \\
\text { endangered by } \\
\text { toxic substance } \\
\text { within [m] }\end{array}$ & $\begin{array}{c}\text { Recommended } \\
\text { investigation } \\
\text { of toxic } \\
\text { concentration } \\
\text { [m] }\end{array}$ & $\begin{array}{c}\text { Evaporation } \\
\text { from puddle: } \\
\text { persons } \\
\text { endangered by } \\
\text { toxic substance } \\
\text { within [m] }\end{array}$ & $\begin{array}{c}\text { Recommended } \\
\text { investigation } \\
\text { of toxic } \\
\text { concentration }\end{array}$ \\
\hline GB 01 & 0,1 & 1200 & 1800 & 500 & 750 \\
\hline GB 02 & 0,2 & 1900 & 2850 & 575 & 863 \\
\hline GB 03 & 0,3 & 2600 & 3900 & 650 & 975 \\
\hline GB 04 & 0,4 & 3300 & 4950 & 725 & 1090 \\
\hline GB 05 & 0,5 & 4000 & 6000 & 800 & 1200 \\
\hline GB 06 & 1 & 6500 & 9700 & 1500 & 2250 \\
\hline GB 07 & 2 & 9000 & 13500 & 2500 & 3750 \\
\hline GB 08 & 3 & 11000 & 16500 & 3200 & 4550 \\
\hline
\end{tabular}

\section{Soman}

The POISON model - warfare chemical agent tabular model (T-SOFT, 2012). Method of substance release: dispersion (explosion, spraying, etc.). Persons endangered by the substance: see Tab. 3. The recommended investigation of toxic concentration is shown in the below table. 
Tab. 3 Potential misuse of soman for chemical terrorism (Source: the author, T-SOFT)

\begin{tabular}{|c|c|c|c|}
\hline $\begin{array}{c}\text { Scenario } \\
\text { code }\end{array}$ & $\begin{array}{c}\text { Contaminated } \\
\text { area [ha] }\end{array}$ & $\begin{array}{c}\text { Persons } \\
\text { endangered } \\
\text { by toxic } \\
\text { substance [m] }\end{array}$ & $\begin{array}{c}\text { Recommended } \\
\text { investigation } \\
\text { of toxic } \\
\text { concentration }\end{array}$ \\
\hline GD 01 & 0,1 & 7000 & 10500 \\
\hline GD 02 & 0,2 & 8700 & 13100 \\
\hline GD 03 & 0,3 & 10500 & 15800 \\
\hline GD 04 & 0,4 & 12300 & 18400 \\
\hline GD 05 & 0,5 & 14000 & 21000 \\
\hline GD 06 & 1 & 17500 & 26300 \\
\hline GD 07 & 2 & 22000 & 33000 \\
\hline GD 08 & 3 & 25500 & 38300 \\
\hline
\end{tabular}

\section{Tabun}

The POISON model - warfare chemical agent - tabular model (T-SOFT, 2012). Method of substance release: dispersion (explosion, spraying, etc.). Persons endangered by the substance and the recommended investigation of toxic concentration is shown in the below table.

Tab. 4 Potential misuse of tabun for chemical terrorism (Source: the author, T-SOFT)

\begin{tabular}{|c|c|c|c|}
\hline $\begin{array}{c}\text { Scenario } \\
\text { code }\end{array}$ & $\begin{array}{c}\text { Contaminated } \\
\text { area [ha] }\end{array}$ & $\begin{array}{c}\text { Persons } \\
\text { endangered } \\
\text { by toxic } \\
\text { substance [m] }\end{array}$ & $\begin{array}{c}\text { Recommended } \\
\text { investigation } \\
\text { of toxic } \\
\text { concentration }\end{array}$ \\
\hline GA 01 & 0,1 & 1000 & 1500 \\
\hline GA 02 & 0,2 & 1700 & 2550 \\
\hline GA 03 & 0,3 & 2400 & 3600 \\
\hline GA 04 & 0,4 & 3100 & 4650 \\
\hline GA 05 & 0,5 & 3800 & 5700 \\
\hline GA 06 & 1 & 5200 & 7800 \\
\hline GA 07 & 2 & 8500 & 12800 \\
\hline GA 08 & 3 & 10500 & 15800 \\
\hline
\end{tabular}

\section{Results of the security SWOT analysis for the Prague Metro focusing on the threat of chemical terrorism}

Based on the data from the analysis of the present state and from the results of modelling by the TEREX program, a SWOT analysis has been carried out for the conditions of chemical terrorism in the Prague Metro. Its results provide us with an overall view of the present state and a possible development of the situation of threat and security related to the threat of a misuse of dangerous chemical substances. The results of the analysis are shown in Tab. 5.
Tab. 5 SWOT Analysis - Chemical terrorism in the conditions of the Prague Metro (Source: the author)

\begin{tabular}{|c|c|}
\hline Strengths (S) & Weaknesses (W) \\
\hline $\begin{array}{l}\text { Protective measures } \\
\text { - short routes/ intervals, } \\
\text { - camera surveillance system, } \\
\text { - fire detection system } \\
\text { Transported persons } \\
\text { - number of transported } \\
\text { persons less than in other world } \\
\text { metropolises, } \\
\text { - no round-the-clock operation } \\
\text { in the Prague Metro } \\
\text { Preventive activities } \\
\text { - preparation of the IES units, } \\
\text { - new type activity for the IES } \\
\text { units } \\
\text { Preparedness and operability } \\
\text { - involvement of IZS units, PIT } \\
\text { (Prague Integrated Transport) } \\
\text { employees, and other } \\
\text { stakeholders, } \\
\text { - increasing preventive } \\
\text { activities, } \\
\text { - carrying out drills in the } \\
\text { Prague Metro } \\
\text { Chemical terrorism } \\
\text { - less danger of chemical } \\
\text { terrorism in the Czech Republic, } \\
\text { - monitoring chemical terrorism } \\
\text { issues not only in the CR } \\
\text { conditions }\end{array}$ & $\begin{array}{l}\text { Protective measures } \\
\text { - detection of dangerous } \\
\text { substances, } \\
\text { - large number of easily } \\
\text { accessible stations, } \\
\text { Transported persons } \\
\text { - thorough control of all } \\
\text { passengers impossible, } \\
\text { - large number of passengers } \\
\text { mainly in the morning and } \\
\text { afternoon hours } \\
\text { Preventive activities } \\
\text { - little experience of the } \\
\text { stakeholders } \\
\text { Preparedness and operability } \\
\text { - knowledge and experience of } \\
\text { PID experts and employees, } \\
\text { - relatively short-term } \\
\text { preventive measures applied } \\
\text { Chemical terrorism } \\
\text { - little or no experience of } \\
\text { chemical terrorism in the Czech } \\
\text { Republic } \\
\text { - little opportunity to check all } \\
\text { suspicious looking persons in } \\
\text { the Metro, } \\
\text { - conditions for quick spreading } \\
\text { of dangerous substance }\end{array}$ \\
\hline Opportunities (O) & Threats (T) \\
\hline $\begin{array}{l}\text { Protective measures } \\
\text { - regular updating and inspection } \\
\text { of security measures, } \\
\text { - increasing security mainly in } \\
\text { the new stations } \\
\text { Transported persons } \\
\text { - regular statistical data feedback } \\
\text { on transported persons, } \\
\text { Preventive activities } \\
\text { - increasing preventive } \\
\text { activities, } \\
\text { - promoting cooperation } \\
\text { between IES units and PIT } \\
\text { employees, } \\
\text { - measures to prevent access to } \\
\text { dangerous substances an stricter } \\
\text { control (monitoring) } \\
\text { Preparedness and operability } \\
\text { - training and educating experts } \\
\text { and PIT employees together } \\
\text { with relevant IES units and other } \\
\text { stakeholders, } \\
\text { - gaining knowledge and } \\
\text { experience from countries } \\
\text { with advanced system of } \\
\text { underground transport, } \\
\text { Chemical terrorism } \\
\text { - learning from foreign } \\
\text { experience }\end{array}$ & $\begin{array}{l}\text { Protective measures } \\
\text { - budget cuts on protective } \\
\text { measures } \\
\text { - outdated protective and } \\
\text { security measures, possible } \\
\text { malfunction in the event of } \\
\text { chemical attack } \\
\text { Transported persons } \\
\text { - large number of persons in } \\
\text { a relatively small space (cars) } \\
\text { - increasing numbers of } \\
\text { transported persons } \\
\text { Preventive activities } \\
\text { - little emphasis on preventive } \\
\text { measures and increased security, } \\
\text { Preparedness and operability } \\
\text { - no great emphasis put on } \\
\text { protection against potential } \\
\text { chemical attack } \\
\text { Chemical terrorism } \\
\text { - hitting even at low } \\
\text { concentrations of dangerous } \\
\text { substance, } \\
\text { - increased threat of a terrorist } \\
\text { attack in the Czech Republic, } \\
\text { - development of new dangerous } \\
\text { substances and methods of their } \\
\text { spreading }\end{array}$ \\
\hline
\end{tabular}




\section{Conclusion}

Chemical terrorism is a serious security threat not only in the Czech Republic, but all over the world. Its imminence and danger is given by many different facts such as the previous experience of actual attacks (Japan), the appearance of new terrorist groups, changes, and reactions to political changes, growing national minorities even in the Czech Republic, religious fanaticism, etc. The requirement of the present time and of the near future is then the need of intensive involvement of governmental intelligence services, which must be constantly occupied by uncovering the preparations of terrorist attacks in order to prevent violence and extortion in cooperation with the police and other public administration bodies.

Concerning the victims of terrorist attacks, these are not only direct victims, dead and wounded persons, but also indirect victims including the families and friends of the victims, and a wider informed public. It is the informed public on which, through the media, the present terrorists count when planning their atrocities to be very brutal to shock the entire public to draw attention to their requirements, attitude to a political situation, etc. Chemical terrorism, which can bring about unfathomable and catastrophic consequences, must be counted to this category, too.
It should be stressed that modelling a chemical terrorist attack along with its devastating impacts is a condition necessary for a thorough scientific investigation in this area.

The data of the SWOT analysis reflect the present state of security and security measures along with the results of the modelling by the TEREX computer programme in the conditions of the Prague Metro. The results provide an overall view of the strengths, weaknesses, threats, and opportunities to strengthen the preparedness, security measures, and prevention. The situation should result in a comprehensively prepared and organized protection of population against chemical terrorism.

In 2013, an important and comprehensive methodology, Model Activity of the Integrated Emergency System (in reaction to a chemical attack in the Metro), was published. Now it is necessary to verify the cooperation and collaboration procedures recommended thoroughly and sensitively in the technical practice, which is only possible in the form of demanding model and comprehensive drills, or in the form of stringent tests of preparedness. The Metro 2014 drill carried out in the much-frequented Anděl station was one of such tests of preparedness for the increasing threat potential in the Czech Republic. The results of this drill will help improve the work of the IES units and increase the security of the critical infrastructure.

\section{References}

ANGELOUDIS, Panagiotis, FISK, David (2006). Large subway systems as complex networks. Physica A: Statistical Mechanics and its Applications. 2006. Vol. 367, pp. 553-558. ISSN 0378-4371.

CAMEO - ALOHA 5.4.4. (2013). ALOHA [software]. EPA. USA, 2013 [cit. 2014-07-09].

DPP (2015). Prague Transport. [online]. Prague Public Transport, 2015. [cit. 2015-01-30]. Available at: http:// www.dpp.cz/ (in Czech).

ENGMAN, K. L., CASSEL, G. (2002). FOI briefing book on chemical weapons - threats, effects and protection, Göteburg, Sweden: OCLC WorldCat, 2002. p. 96. ISBN 91-7056-110-9.

KLOUDA, Karel (2008). Underground structures as a component of critical infrastructure, In 5th International conference of Crisis management „Civil Protection 2008“, conference proceedings, pp. 163 - 170, Brno 2008, ISBN 978-80-7231-510-9 (in Czech).

KLOUDA, Karel, BRÁDKA, Stanislav, NEPLECHOVÁ, Jana (2007). Information about the course of modeling the spread of chemical agents in the metro stations. In 16th International conference „Fire Protection 2007“, conference proceedings, Ostrava, 2007. pp. 228-238. ISBN 978-80-7385-009-8 (in Czech).

KLOUDA, Karel, WITKOVSKÁ, Věra, BRÁDKA, Stanislav, CEJPEK, Jiří (2011). The Propagation of the Substituent Poisonous Matter after his Release into the Waggon of the Underground. In 20th International conference „Fire Protection 2011 “, conference proceeding, pp. 129 - 133. ISBN 978-80-7385-102-6, ISSN 1803-1803 (in Czech).

KOENIG Kristi L., BOATRIGT Connie J., HANCOCK, John A., DENNY, Frank J., TEETER, David S., KAHN, Christopher, SHULTZ Carl H. (2007). Health care facilities' "war on terrorism”: a deliberate process for recommending personal protective equipment, The American Journal of Emergency Medicine, V West Bethesda, MD, USA, 2007, Vol. 25, No. 2, pp. 185-195. ISSN 0735-6757. 
KONEČNÝ, Jaromír (2013). Reactions to chemical attack in the underground. Journal 112. [online]. 2013, Vol. XII, No. 10. [cit. 2014-05-15]. Available at: http:/www.hzscr.cz/clanek/casopis-112-rocnik-xiicislo-10-2013.aspx?q=Y2hudW09Mg\%3d\%3d. (in Czech).

KOZUBKOVÁ, Milada, KLOUDA, Karel, BOJKO, Marian (2008). Influence of Boundary Conditions on the Air Flow Inside the Subway Station of Muzeum C-A Area and Comparison of Numerical and Physical Results of Warfare Compound Substtuent Diffusion, Transactions of the VŠB - Technical University of Ostrava, Civil Engineering Series, Ostrava 2008, Vol. 3, No. 1. ISBN 978-80-248-1891-7 (in Czech).

KOZUBKOVÁ, Milada (2015). The fluid flow modeling Fluent, CFX. [online]. Ostrava: VŠB-TU, 2008 [cit.: 2014-11-30]. Available at: http://www.338.vsb.cz/PDF/Kozubkova-Fluent.pdf (in Czech).

Management Mania. (2013). SWOT analysis [online]. Managament Mania, Business encyclopedia, Plzeň, 2013 [cit. 2014-09-12]. Available at: https://managementmania.com/cs/swot-analyza (in Czech).

MATOUŠEK Jiř́, LINHART, Petr (2005). CBRN: Chemical weapons. Ostrava: Association of Fire and Safety Engineering - SPBI, 2005. 151 s. ISBN 80-86634-71-X (in Czech).

MARRS T. C., MAYNARD R. L., SIDELL F. R. (2007). Chemical Warfare Agents, Toxicology and Treatment, 2nd edit., Chichester, United Kingdom: Jonh Wiley and Sons, Ltd., 2007, 93 p. ISBN 978-0-470-01359-5.

MAŠEK, Ivan, MIKA, Otakar. J., KAPOUN, Michal (2008). Protection against the effects of chemical terorrism (set of specialized lectures). Brno: Brno University of Technology, Faculty of Chemistry, 2008 (in Czech)

MIKA, Otakar, J., PATOČKA, Jiří (2007). Protection against chemical terrorism, Vol. 1. České Budějovice: University of South Bohemia in České Budějovice, 2007, pp. 107. ISBN 978-80-7040-934-3 (in Czech).

MIKA, Otakar. J. (2008). Terrorist attack with hazardous chemical toxic substances on underground. The Science for Population Protection, Lázně Bohdaneč, 2008, pp. 91-98. ISSN: 1803-568X (in Czech).

MIKA, Otakar, J. (2011). Chemical terrorism in underground. SECURITY, Praha, 2011, vol. 15, no. 1, pp. 59-63. ISSN 1210- 8723 (in Czech).

MIKA, Otakar, J. (2011). Civil protection against chemical terrorism in the Czech Republic. [Habilitation Thesis], Brno University of Technology, Faculty of Chemistry, Brno, pp. 188. 2011 (in Czech).

MIKA, Otakar. J. (2013). Chemical and Toxicological Aspects of Chemical Terorrism in Japan. In: Volunteer Firefighter 2013, conference proceeding. Brno: Moravian Firefighters Union, 2013, pp. 44-62. ISBN 978-80903586-2-1 (in Czech).

MIKA, Otakar. J., MAŠEK, I., ANDREEVA, E. (2007). The main hazard from chemical terrorism and countermeasures for protection of citizens at present in the Czech Republic. Rapporteur of civil defense, Brno, 2007, Vol. 2007, No. 02, pp. 39-56. ISSN 1221-2593 (in Czech).

NEPLECHOVÁ, J., KLOUDA, K. (2008). Review of the air shaft systém of Prague's metro in light of their possible abuse or threat to the people and the environment. In: 5th International conference of Crisis management „Civil Protection 2008“, conference proceedings, pp. 278 - 287, Brno 2008. ISBN 978-80-7231-510-9 (in Czech).

OKUMURA, Tetsu, TAKASU, Nobukatsu, ISHIMATSU, Shinichi, MIYANOKI, Shou, MITSUHASHI, Akihiro, KUMADA Keisuke, TANAKA Kazutoyo, HINOHARA Shigeaki (1996). Report on 640 Victims of the Tokyo Subway Sarin Attack. Annuals of Emergency Medicine, California, USA, 1996, Vol. 28, Issue 2, pp. 129-135. ISSN 0196-0644.

POKORNÝ, Jakub (2014). Czech Muslims are good, only occasionally slip in the sermon, says Arabist [online]. Praha: iDNES.cz, 2014 [cit. 2014-08-09]. Available at: http://zpravy.idnes.cz/v-cesku-je-asi-deset-tisicmuslimu-rika-arabista-f5r-/domaci.aspx?c=A140726_110208_domaci_jp (in Czech).

Statistical Report (2013). Prague Statistical Yearbook [online]. Praha: Czech Statistical Office 2013 [cit. 2014-0608]. Available at: http://www.czso.cz/csu/2013edicniplan.nsf/krajkapitola/101011-13-r_2013-17 (in Czech).

T-SOFT (2012). TEREX - Terrorist Expert [software]. Praha, 2012. [cit. 2014-03-13]. (in Czech).

VEČERKOVÁ, Jana; KLOUDA, Karel (2009). Evacuation of passengers from the Prague subway. In: Civil Protection 2009, conference proceedings. Ostrava, 2009, pp. 319 - 322. ISBN 978-80-7385-059-3 (in Czech). 